\title{
Psychometric Properties of the Psychological Capital Scale in the Student Context (PsyCap-S)
}

\author{
Fabiola Rodrigues Matos ${ }^{1}$ \\ Alexsandro Luiz De Andrade ${ }^{1}$
}

\begin{abstract}
The resources provided by psychological capital can contribute to the successful academic performance of students, as well as to overcome obstacles and achieve established goals. There is an absence of a Brazilian instrument to measure psychological capital in students. Thus, this study aimed to develop and to seek evidence for the validity and accuracy of the psychological capital scale in the student context (PsyCap-S). The research was conducted based on two studies, with 697 students in each. In both samples the majority was composed of females who intended to enter undergraduate studies. The results indicated the validity and reliability of a structure of four dimensions (resilience, hope, self-efficacy, and optimism). Theoretical and practical dimensions of using the instrument are discussed, as well as implications for intervention in the context of the studies.
\end{abstract}

Keywords: students, psychometrics, self-efficacy, optimism, hope

\section{Propriedades Psicométricas da Escala de Capital Psicológico no Contexto de Estudos (PsyCap-E)}

\begin{abstract}
Resumo: Os recursos proporcionados pelo capital psicológico podem contribuir para o bom desempenho acadêmico de estudantes, bem como para superar obstáculos e atingir metas estabelecidas. Há a ausência de um instrumento brasileiro para mensuração de capital psicológico em estudantes. Este estudo teve por objetivo desenvolver e buscar evidências de validade e precisão da Escala de Capital Psicológico no contexto de Estudos (PsyCap-E). A pesquisa foi realizada com base em dois estudos, com 697 estudantes em cada um, sendo que em ambas as amostras a maior parte era mulher e pretendia ingressar na graduação. Os resultados indicaram que a escala apresentou indicadores de validade e confiabilidade para uma estrutura de quatro dimensões (resiliência, esperança, autoeficácia e otimismo). Discutem-se dimensões teóricas e práticas do uso do instrumento, bem como implicações para intervenção no contexto dos estudos.
\end{abstract}

Palavras-chave: estudantes, psicometria, autoeficácia, otimismo, esperança

\section{Propiedades Psicométricas de la Escala de Capital Psicológico en el Contexto de Estudios (PsyCap-E)}

\begin{abstract}
Resumen: Los recursos proporcionados por el capital psicológico pueden contribuir al buen desempeño académico de los estudiantes, así como a superar obstáculos y alcanzar metas establecidas. Existe una ausencia de un instrumento brasileño para medir el capital psicológico en los estudiantes. Este estudio tuvo como objetivo desarrollar y buscar evidencia de validez y precisión para la Escala de Capital Psicológico en el contexto de Estudios (PsyCap-E) en contexto brasileño. La investigación se llevó a cabo en dos estudios, con 697 estudiantes en cada uno, la mayoría de los cuales en ambas muestras eran mujeres y tenían intención de ingresar en una universidad. Los resultados indicaron que la escala presentó indicadores de validez y de confiabilidad para estructura de cuatro dimensiones (resiliencia, esperanza, autoeficacia y optimismo). Se discuten las dimensiones teóricas y prácticas del uso del instrumento, así como sus implicaciones para la intervención en el contexto de los estudios.
\end{abstract}

Palabras clave: estudiantes, psicometría, autoeficacia, optimismo, esperanza

${ }^{1}$ Universidade Federal do Espirito Santo, Vitória-ES, Brazil

Article based on the first author's doctoral dissertation under the supervision of the second author, defended in 2021, at the Post-graduate Program in Psychology of the Universidade Federal do Espírito Santo. Support: First author: CAPES-DS financial support (doctoral grant April/2018-July/2019). Second author: Financial support from CNPq. - process No. 308323 / 2018 1; FAPES (Term of Grant 226/2019).

Correspondence address: Fabiola Rodrigues Matos. Universidade Federal do Espírito Santo. Av. Fernando Ferrari, s/n, Vitória-ES, Brazil. CEP 29.075-910. E-mail: fabiolarmatos@yahoo.com.br
Positive psychology was developed in the 21 st century with the intention of shifting the central focus fixed on pathology that existed in the context of psychology to a positive bias (Seligman, Ernst, Gillham, Reivich, \& Linkins, 2009). Among the concepts addressed by this psychology is psychological capital (PsyCap), developed by Luthans, Avolio, Avey, and Norman (2007), which is concerned with investigating human behavior related to positive capabilities that promote personal growth and development. Although PsyCap originated 
in the organizational context and much research has been conducted in that context, it can also play an important role in the educational context (Datu, King, \& Valdez, 2016).

PsyCap is a positive state consisting of four psychological capacities: self-efficacy, optimism, hope, and resilience (Hazan Liran \& Miller, 2019; Luthans et al., 2007). In the student context these psychological capacities manifest themselves as students evaluate their current situation and the likelihood of success by maintaining a positive perspective (optimism), being more likely to invest the effort and perseverance needed to succeed, believing in themselves (self-efficacy), being determined to succeed (hope), and learning and growing from challenges (resilience) (Martinez, Youssef-Morgan, Chambel, \& Marques-Pinto, 2019).

A student who accumulates the personal resources that constitute the PsyCap (hope, self-efficacy, resilience, and optimism) exhibits specific skills and behaviors necessary to meet educational requirements and achieve academic success (Carmona-Halty, Schaufeli, \& Salanova, 2019). It is understood that the resources provided by PsyCap can contribute to academic performance (Martínez, YoussefMorgan, et al., 2019), as well as assist in overcoming obstacles, achieving goals, and facing more difficult and delicate situations in life (Harms, Krasikova, \& Luthans, 2018). Thus, in the educational context, PsyCap facilitates the processes necessary for attention, interpretation, and retention of positive and constructive memories that guide well-being and good performance (Carmona-Halty, Schaufeli, et al., 2019), and is positively related to engagement with learning (Datu et al., 2016).

Research investigating PsyCap in samples of high school students, such as the study of Datu et al. (2016) in the Philippines showed direct and significant associations of the construct with improved academic performance. A second study with the same sample indicated correlation of PsyCap to greater engagement in studies (Datu \& Valdez, 2016). In Chile, another study with high school students associated PsyCap with increased academic performance (Carmona-Halty, Salanova, Llorens, \& Schaufeli, 2019).

Regarding undergraduate students, a research in Israel indicated that PsyCap improved student motivation (Hazan Liran \& Miller, 2019), and in China results suggested increases in learning empowerment correlated to the construct (Liao \& Liu, 2016). Also in China, research in the university context also showed that PsyCap partially mediated the association between social exclusion and depression ( $\mathrm{Li}, \mathrm{Zhao}, \& \mathrm{Yu}, 2021)$. Furthermore, the development of this construct significantly increased the positive mental health of North Americans (Selvaraj \& Bhat, 2018), as well as negatively correlated with anxiety in a sample of Chinese college students (Wu, $\mathrm{Xu}$, Zhang, \& Liu, 2019).

Some studies adapted items from work-related scales to assess PsyCap in educational contexts, whereas others had other scales as theoretical basis or constructed instruments according to the literature in the area. For example, Adil, Ameer, and Ghayas (2020) developed a measure of PsyCap for Pakistani students by grouping other scales already developed. A Spanish version of the Psychological Capital Questionnaire (PCQ) was developed in Spain and Chile, (Martínez, Meneghel, Carmona-Halty, \& Youssef-Morgan, 2019), and was also adapted in Argentina (Schönfeld \& Mesurado, 2020). Still in the student context, there is also the instrument by Luthans,
Luthans, and Avey (2013), the Academic Psychological Capital, developed in the United States.

In Brazil, the PCQ-24 instrument (Cid, Martins, Dias, $\&$ Fidelis, 2020) is used to assess PsyCap in organizational contexts. Furthermore, a reduced version of this instrument (PCQ-12) was developed by Kamei et al. (2018). The Inventory of Psychological Capital at Work - ICPT-12 (Siqueira, Martins, \& Souza, 2014) brings a version with fewer items for measurement. However, to date, there is no scale developed to assess PsyCap in student contexts in the country.

Considering the scarcity of studies on the subject and the absence of a Brazilian instrument for measurement, the overall aim of this research was to develop and to seek evidence of validity and accuracy of the PsyCap-S. To this end, two studies were conducted presenting specific objectives to adequately develop the technical guidelines of the International Test Commission [ITC] (2017). Study 1 aimed to construct the PsyCap-S, seeking to raise evidence of content validity, as well as obtaining a preliminary version of the instrument from exploratory factor analysis. And Study 2 aimed to confirm the best structure for the PsyCap-S in the Brazilian context, as well as raising converging and diverging evidence for construct validity.

\section{Study 1 Method}

\section{Participants}

The sample was composed of 697 students, whose majority was women $(84.1 \% ; N=578)$ and a mean age of 19.12 $(S D=3.16)$. The participants belonged to 25 Brazilian states and the Federal District, except for Roraima, which had no representatives in the sample. The states with the largest number of participants were Espírito Santo $(N=128 ; 18.6 \%)$, São Paulo $(N=108 ; 15.7 \%)$, and Minas Gerais $(N=86 ; 12.5 \%)$. Regarding marital status, there was a higher concentration of single people $(N=656 ; 95.5 \%)$. Out of the total respondents, $88.2 \%$ did not work, $98.4 \%$ had no children, $75.4 \%$ lived with their parents, and $34.4 \%$ earned one to three minimum wages. Finally, in relation to the characteristics related to the student context of the sample, the majority intended to enroll in an undergraduate course $(96.1 \%$; $N=660)$, had already chosen the course $(83.3 \% ; N=572)$, and $63.80 \%(N=438)$ intended to enroll in a public university.

\section{Instruments}

The participants answered a sociodemographic questionnaire (consisting of questions such as age, gender, marital status, income, region where they live, among others); along with the PsyCap-S Scale (developed in this study).

\section{Procedures}

The PsyCap-S was built using the theoretical foundations related to PsyCap (Luthans, Youssef-Morgan, \& Avolio, 2015; Martínez, Youssef-Morgan, et al., 2019), as well as the study of Siqueira et al. (2014) that presented a reduced version of a measure aimed to evaluate PsyCap in the work environment. Three items representing each of the dimensions of PsyCap were structured (total of 12 items), divided into the dimensions of self-efficacy (confidence to take on and make the effort necessary to succeed at challenging tasks), optimism (making positive attribution about success now and in the future), hope 
(persevering toward goals and, when necessary, redirecting paths to achieve success), and resilience (when faced with adversity, the individual resists pressure, overcoming obstacles to achieve their purpose). Items were structured for response by a fivepoint Likert scale $(1=$ strongly disagree to $5=$ strongly agree $)$.

The item construction and content adaptations were performed by the authors and later submitted to expert judgment, raising evidence of the instrument content validity. At this stage, five experts who held a master's degree and worked directly with aspects of students' careers and mental health participated. An online questionnaire was made available containing the items that should be evaluated according to categories related to content and its representativeness in each dimension. All procedures were performed according to the technical guidelines of the International Test Commission (ITC, 2017). Thus, the preliminary version of the scale was defined, answered in a pilot study with a sample of 12 students ( 2 males and 10 females). There were no modifications with the pilot study and then the empirical study was conducted to evaluate the internal structure and the survey of general psychometric evidence.

Data collection. An online form was developed in the Google Forms application with the instruments used in this research and the sociodemographic questionnaire. The preservation of the confidentiality of individual responses was guaranteed at all times. Before accessing the questionnaire, the participants were asked to fill out the informed consent form. Thus, access was only allowed to those who agreed to participate in the research on a voluntary basis. The invitation was made available through a link, and sent by messages on Facebook, WhatsApp, Twitter, and Instagram. Data collection was carried out from August/2019 to January/2020.

Data analysis. Evidence from the content validity of the instrument was initially assessed by using the Content Validity Coefficient (CVC) proposed by Hernández Nieto (2002). It was calculated according to the judgment of experts regarding the categories of clarity of language, and practical and theoretical relevance. The study of the adequacy of each item to the corresponding theoretical dimension was performed using Kappa Concordance Analysis (Siegel \& Castellan, 1988).
For the CVC, items with a result equal to or greater than 0.80 were characterized as adequate; when they presented values between 0.79 and 0.70 were considered adequate; and results with values between 0.69 and 0.60 were admitted only for research use (Cassep-Borges, Balbinotti, \& Teodoro, 2010). For Kappa Concordance Analysis, only dimensions with a result above 0.40 present adequate agreement, and the closer to one (1), the more satisfactory the result (Landis \& Koch, 1977).

After the theoretical and empirical analysis, the analysis of the internal factor structure of the instrument was conducted, first evaluating the cases not covered, which were treated by Expectation Maximization (EM). No discrepant data was observed through Mahalanobis distance analysis. The Exploratory Factor Analysis (EFA) was performed with the help of a parallel analysis to decide the number of factors to be extracted. Concomitantly, the extraction of the factors suggested via EFA was performed from the polycorrelation matrix (Freiberg Hoffmann, Stover, de la Iglesia, \& Fernández Liporace, 2013), with extraction of the factors by the method of Minimum Factor Analysis (MRFA). The software used in this procedure was Factor version 10.10 (Ferrando \& Lorenzo-Seva, 2017).

\section{Ethical Considerations}

The research was approved by the Research Ethics Committee of the Universidade Federal do Espírito Santo (CAAE number 12681519,8,0000,5542 Opinion number $3,463,117)$. The participants in this research agreed to participate in the study by signing and agreeing with the informed consent form.

\section{Results}

\section{Evidence of content validity}

Based on the experts' analysis of the scale content, the CVC indices were calculated as shown in Table 1.

Table 1

Items developed in their respective dimensions and calculation of the content validity coefficient

\begin{tabular}{|c|c|c|c|c|}
\hline Item & Dimension & 1 & 2 & 3 \\
\hline 1. I hope to have enough knowledge to grow through my studies. & Hope & 0.95 & 0.95 & 0.95 \\
\hline 2. I can find many ways to fulfill my dreams through my studies & Hope & 0.99 & 0.95 & 0.91 \\
\hline 3. I am able to keep up with the technologies that can be used in my studies & Self-efficacy & 0.95 & 0.91 & 0.95 \\
\hline 4. I believe better days will come through my studies & Optimism & 0.91 & 0.91 & 0.95 \\
\hline 5. I get stronger after facing failures in my studies & Resilience & 0.95 & 0.95 & 0.95 \\
\hline 6. I hope to have enough experience to be successful through my studies. & Hope & 0.99 & 0.99 & 0.99 \\
\hline 7. I am able to easily learn new content that arises in my studies & self-efficacy & 0.99 & 0.99 & 0.99 \\
\hline 8. I believe that good things will happen to me through my studies & Optimism & 0.95 & 0.87 & 0.95 \\
\hline 9. I can understand complex content in my studies & Self-efficacy & 0.95 & 0.67 & 0.91 \\
\hline $\begin{array}{l}\text { 10. I get stronger when I face intrigues (for example: interpersonal conflicts, } \\
\text { judgments, criticisms, etc.) in my study environment }\end{array}$ & Resilience & 0.91 & 0.99 & 0.99 \\
\hline 11. I believe that tomorrow will be better through my studies & Optimism & 091 & 0.99 & 0.99 \\
\hline 12. I feel stronger when facing competition in my study environment & Resilience & 0.91 & 0.95 & 0.99 \\
\hline
\end{tabular}

Note. 1 = Clarity of language; $2=$ Practical relevance; $3=$ Theoretical relevance 
According to Table 1, all items presented adequate results regarding their content $(\mathrm{CVC}>0.80)$, except for item 9 , which showed a lower value $(0.67)$ in the practical relevance category, but still acceptable for use in research (Cassep-Borges et al., 2010), corroborating the expected applicability of this instrument. Regarding the Kappa concordance analysis, the dimensions of hope $(0.51 ; 63.30 \%$ agreement $)$, resilience $(0.64 ; 73.30 \%$ agreement), and self-efficacy $(0.82 ; 86.67 \%)$ showed adequate results, indicating that the experts judged the items belonging to each of these factors as representative to them, according to their content. However, the optimism dimension obtained a result lower than indicated (Kappa $>0.40$ ), considered reasonable (Landis \& Koch, 1977), since it presented a Kappa index value of 0.29 and $46.67 \%$ agreement among the specialists. Considering the good results presented by the CVC on items 4,8 and 11 , representative of optimism and that the CVC indicates if the content effectively explores the questions for measuring a certain phenomenon to be investigated, it was decided to proceed to the factor analysis without the exclusion of items from the scale.

\section{Evidence of the internal structure of the PsyCap-S}

Firstly, the quality of the data matrix was evaluated by Exploratory Factor Analysis procedures, and was considered factorable, with interpretation of the item correlation matrix through the results of the Bartlett's test of sphericity ( $4538.6 \mathrm{df}$ $=66, \mathrm{p}<0.001)$ and $\mathrm{KMO}(0.87)$. In the process of deciding the internal factor structure, it was verified from the parallel analysis the suggested solution with 2 factors (Empirical eigenvalues: $\mathrm{F} 1=47,29 ; \mathrm{F} 2=15.79 ; \mathrm{F} 3=8.85$; Random eigenvalues: $\mathrm{F} 1$ $=16.85 ; \mathrm{F} 2=15.02 ; \mathrm{F} 3=13.40$ ) as representative for the data from the first part of the sample, with explained variance of $67 \%$. Table 2 presents the items and the factor loadings extracted.

In theoretical terms, regarding PsyCap, although selfefficacy, optimism, hope and resilience are conceptually distinct, these four components share common variations and are part of a synergistic set of resources (Hobfoll, 2002). According to the results of the EFA, all hope and optimism items clustered on factor 2, all resilience items clustered on factor 1, and selfefficacy was the only construct that had items on both factors.

Table 2

Factor loadings of the model according to the Exploratory Factor Analysis

\begin{tabular}{cccc}
\hline Item & $\mathrm{F} 1$ & $\mathrm{~F} 2$ & $\left(\mathrm{~h}^{2}\right)$ \\
\hline Item 1 & & 0.70 & 0.42 \\
Item 2 & & 0.73 & 0.49 \\
Item 3 & & 0.39 & 0.30 \\
Item 4 & & 089 & 0.78 \\
Item 5 & 0.61 & & 0.40 \\
Item 6 & & 0.82 & 0.58 \\
Item 7 & 0.70 & & 0.45 \\
Item 8 & & 0.80 & 0.68 \\
Item 9 & 0.73 & & 0.51 \\
Item 10 & 0.69 & & 0.48 \\
Item 11 & & 0.79 & 0.69 \\
Item 12 & 0.66 & & 0.51 \\
\hline
\end{tabular}

\section{Study 2 \\ Method}

\section{Participants}

The sample was composed of 697 students, whose majority was composed of women $(79.3 \% ; N=553)$ and a mean age of $19.01(S D=3.31)$. The participants belonged to 25 Brazilian states and the Federal District, except for Roraima, which had no representatives in the sample. The states with the most participants were São Paulo $(N=110 ; 15.8 \%)$, Minas Gerais $(N=109 ; 15.6 \%)$, and Bahia $(N=52 ; 7.5 \%)$. Regarding marital status, there was a higher concentration of single people $(N=680 ; 97.6 \%)$, followed by stable union $(N=11 ; 1.6 \%)$. Out of the total respondents, $86.5 \%$ did not work, $99 \%$ had no children, $72.9 \%$ lived with their parents, and $40.5 \%$ earned one to three minimum wages. Finally, in relation to the characteristics related to the student context of the sample, the majority intended to enroll in an undergraduate course $(94.5 \% ; N=659)$, had already chosen which course to take $(83.4 \% ; N=581)$, and intended to register in a public college $(64.8 \% ; N=452)$.

\section{Instruments}

The data collection form featured a sociodemographic data section and three psychometric instruments as description that follows. PsyCap-S Scale. Instrument developed in this study.

Positive and Negative Affect Scale for Adolescents (Segabinazi et al., 2012). Consisting of 28 adjectives describing positive (e.g., happy, loving, and willing; $\alpha=0.88 ; 27.26 \%$ variance) and negative (e.g., upset, guilty, and impatient; $\alpha=0.88 ; 12.04 \%$ variance) subjective affective states. Items are answered according to a five-point Likert scale (ranging from $1=$ Not at all to $5=$ Very much).

Depression, Anxiety, and Stress Scale for Adolescents (ADSS-A) (Patias, Machado, Bandeira, \& Dell'Aglio, 2016). Composed of three subscales to assess symptoms of depression (e.g. "I couldn't have positive feelings"; $\alpha=0.90$ ), anxiety (e.g. "I realized my mouth went dry"; $\alpha=0.83$ ), and stress (e.g. "I had trouble calming down"; $\alpha=0.86$ ). Each subscale contains seven items, answered by a four-point Likert-type scale $(0=$ "It did not happen to me during this week" to $3=$ Happened to me most of the week) and exhibits good psychometric quality $\left[\mathrm{c}^{2}=366.16(186), \mathrm{p}<0.001, \mathrm{CFI}=0.96, \mathrm{TLI}=0.96\right.$, RMSEA $=0.047$ (0.040 - 0.054)].

\section{Procedures}

Data collection. The steps described in Study 1 were followed.

Data analysis. To analyze the data, confirmatory factor analyses were performed, using the Weighted Least Square Mean and Variance Adjusted (WLSMV) estimator. Three different models were tested to verify which best fit the data: model 1 (M1), with two factors (as indicated by the EFA of study 1); model 2 (M2), represented by a secondorder factor and four first-order factors; and model 3 (M3), with four correlated factors. Brown's (2006) recommendation was used to verify the fit of the models, with the $\mathrm{SB} \chi 2$ index on degrees of freedom (SB $\chi 2 / \mathrm{df})$; the Root-Mean-Square Error 
of Approximation (RMSEA); Tucker-Lewis Index (TLI), and Comparative Fit Index (CFI) (Byrne, 2010). This step of the data analysis was performed in R software (R Core Team, 2017), using the Lavaan package (Rosseel, 2012). The internal consistency of the instrument was measured by analyzing the Omega precision indicators using the $\mathrm{R}$ software, with values above 0.70 being considered evidence of adequate reliability (Peters, 2014).

To assess the invariance of the item parameters between the sex-separated groups, Multigroup Factor Analysis (Franco, Valentini, \& Iglesias, 2017) in R software was used. In this analysis, configural, metric, and scalar invariances were tested between male and female participants. Finally, to gather converging and diverging evidence of the PsyCap-S, the correlations of the instrument with the global scores of the measures related to it were calculated. Correlations lower than 0.30 were considered weak, those between 0.30 and 0.50 were considered moderate, and those above 0.50 were considered strong (Mukaka, 2012).

\section{Ethical Considerations}

The research was approved by the Research Ethics Committee of the Universidade Federal do Espírito
Santo (CAAE number $12681519,8,0000,5542$ Opinion No. 3,463,117). The participants in this research expressed their agreement to answer the survey by signing and agreeing to the Informed Consent Form.

\section{Results}

\section{Confirmatory Factor Analysis}

In order to evaluate the best structure of the PsyCap-S in the Brazilian context, we tested three models with Confirmatory Factor Analysis (CFA). We tested a two-factor model (Model 1, as indicated by the CFA); a model of a second-order factor and four first-order factors (Model 2, according to the original theoretical preposition of Luthans, Avey, Avolio, \& Peterson 2010); and a model of four correlated factors (Model 3, according to results already found in similar studies Viseu et al., 2012). Table 3 presents the fit and precision indicators, at the significance level $p<0.001$, for the three models and their respective dimensions.

Table 3

Proposed models from Confirmatory Factor Analysis

\begin{tabular}{|c|c|c|c|c|c|c|c|c|}
\hline Model & $\mathrm{X}^{2} / \mathrm{df}$ & RMSEA $(90 \% \mathrm{CI})$ & TLI & CFI & $\Omega \mathrm{F} 1$ & $\Omega F 2$ & SF3 & $\Omega F 4$ \\
\hline M1 & 7.81 & $0.10(0.09-0.10)$ & 0.94 & 0.95 & 0.77 & 0.82 & - & - \\
\hline M2 & 9.57 & $0.11(0.10-0.12)$ & 0.92 & 0.94 & 0.62 & 0.70 & 0.73 & 0.85 \\
\hline M3 & 3.59 & $0.06(0.06-0.07)$ & 0.92 & 0.94 & 0.62 & 0.70 & 0.73 & 0.85 \\
\hline \multicolumn{9}{|c|}{ Multigroup by sex } \\
\hline Type of invariance & $\mathrm{X}^{2} / \mathrm{df}$ & RMSEA $(90 \% \mathrm{CI})$ & TLI & CFI & $\Delta \mathrm{CFI}$ & & & \\
\hline Configural Invariance & 4.57 & $0.07[0.06-0.07]$ & 0.91 & 0.93 & - & & & \\
\hline Metric Invariance & 4.25 & $0.06[0.06-0.07]$ & 0.92 & 0.93 & 0.00 & & & \\
\hline Scalar Invariance & 4,08 & $0.06[0.06-0.07]$ & 0.92 & 0.93 & 0.00 & & & \\
\hline
\end{tabular}

Note. Model 1 = two factors according to EFA; Model 2 = one second-order factor and four first-order factors; Model $3=$ four correlated factors; $*=p<0.001$.

Model 3 presented better fit indicators among the propositions tested. Propositions 1 and 2 did not present all acceptable indexes, having RMSEA values lower than necessary. Based on the best fit model (M3), the analysis of configural, metric, and scalar invariance of PsyCap-S by gender (males and females) was performed, as shown in Table 3 . The data reveal configural, metric, and scalar invariance for the sex variable, indicating adequacy of the instruments when comparing men and women.

\section{Converging and diverging evidence}

Pearson correlations were tested with measures adapted to the Brazilian context of relevant phenomena to the axiological network of PsyCap-S. The results indicated that the hope dimension was weakly and positively associated with positive affections $(r=0.19)$ and weakly and negatively associated with depression $(r=-0.12)$. Optimism showed a weak and positive association with positive affect $(r=0.29)$ and a weak and negative association with depression $(r=-0.27)$. On the other hand, resilience showed significant correlations with all constructs, being negatively and weakly correlated with stress $(r=-0.25)$, anxiety $(r=-0.20)$, negative affect $(r=-0.30)$, moderately correlated with depression $(r=-0.34)$, and positively and moderately correlated with positive affect $(r=0.40)$. Finally, self-efficacy showed negative and weak correlations with negative affect $(r=-0.19)$, stress $(r=-0.17)$, anxiety $(r=-0.15)$, and depression $(r=-0.24)$, and positive and moderate with positive affect $(r=0.31)$.

\section{Discussion}

This research sought to develop the PsyCap-S to assess the PsyCap resources in Brazilian students. The procedures were divided into two stages: Study 1 aimed at developing the instrument, raising evidence of content validity and analyzing the factor structure of the scale through the EFA; and Study 
2 aimed at indicating the best structure of PsyCap-S in the Brazilian context through the CFA and raising evidence of converging and diverging validity with anxiety, depression, stress, and positive and negative affect.

From the analyses performed in Study 1, it was found through the CVC that all items presented good results regarding semantics and importance. In relation to Kappa concordance analysis, the dimensions hope, resilience, and self-efficacy showed adequate results, considering that the experts who judged the items belonging to each of these factors are representative according to their content. However, the optimism dimension obtained results lower than those indicated as reasonable (Kappa $>0.40$ ). Based on this, we decided to keep the items in view of the adequate result found in this factor when the CVC analysis was performed.

The results from the EFA indicated a two-factor structure for the developed scale. As already mentioned, the four factors that constitute PsyCap share common variations and are part of a synergistic set of resources (Hobfoll, 2002), which justifies the grouping of items representing hope and optimism in one factor, and all resilience items grouped in the other factor, with only self-efficacy being the construct that had items shared in both factors in the EFA. Moreover, understanding PsyCap as an integrative approach, the dimensions share similarities in their operationalization. For example, hope and optimism contribute to facing challenges, self-efficacy assists in developing strategies and paths to success, and resilience leads entrepreneurs to overcome difficulties (Lima \& Nassif, 2017).

Study 2 was designed to test different structural models of the scale, confirming the best structure of the PsyCap-S in the Brazilian context through the evidence of converging and diverging construct validity. For this step, three models were developed and tested, aiming at the best fit. We tested the model indicated by the EFA, the one-factor second-order model, and the four-factor correlated model. These models were chosen to perform the CFA considering that there is no consensus as to how the construct should be interpreted, being first or second order (Luthans et al., 2010; Viseu et al., 2012). The four-factor correlated model was the one that presented the best fit indices, a result that was also found in studies that sought to raise validity evidence of the PCQ-12 for the labor context in Brazil (Viseu et al., 2012) and the PCQ adapted for students in Argentina (Schönfeld \& Mesurado, 2020). Thus, the scale of the model studied is indicated for further use in other research.

As for the converging and diverging evidence, it is found that all dimensions of PsyCap showed a negative association with depression, corroboratingthe Bakker, Lyons, and Conlon (2017) study that indicated associations between such constructs, for example. All dimensions of PsyCap correlated positively with positive affect, a result also found in Singhal and Rastogi's (2018) study, which addressed the influence of PsyCap on subjective well-being in the workplace. Selfefficacy showed significant and negative correlations with stress and anxiety. Consistently, Ersan, Fişekçioğlu, Dölekoğlu, Oktay, and İlgüy (2017) indicated in their research a negative association between stress and self-efficacy in Turkish students, as well as what was found in other studies, such as in students from Indonesia (Qudsyi \& Putri, 2016). In addition, research indicates a negative association between resilience and stress in Chinese students (Smith \& Yang, 2017), and resilience and anxiety for academic exams in Spanish students (Trigueros et al., 2020), results that are similar those found in this study.

Despite the differentiation in the results found by the EFA, the PsyCap-S presented good fit indices and internal consistency and its structural model is consistent with other studies in the area. Even so, it is important to mention the limitations that this research presents, which are related to the sample having a greater coverage in the southeastern states, which would mean less representativeness from other Brazilian regions. In addition, there is the difficulty of having measures in Portuguese that provide more evidence of converging and diverging constructs in the student context, which also justifies the significant but weak relationships between dimensions and related constructs. We suggest the evaluation of the accuracy of the measurement by methods of score comparison over time. They were not performed in this study, but by test-retest methods may enhance the evaluation of reliability.

Despite the limitations presented, this article brought an instrument available for the assessment of PsyCap-S, entailing possible collaborations in investigations aimed at exploring students' self-knowledge and resources, as well as assessing whether the construct predicts good results in higher education entrance exams, for example, since these provide increased academic performance (Martínez, Youssef-Morgan, et al., 2019). Future research may also conduct comparisons of the construct across genders, as this study's test of invariance allows for this applicability. We also suggest longitudinal studies evaluating student performance through the use of interventions focused on the development of PsyCap in the educational context. Finally, PsyCap-S has the potential to be an important tool for data collection and subsequent interventions in educational settings. The instrument is available for open and free access by contacting the authors of this article.

\section{References}

Adil, A., Ameer, S., \& Ghayas, S. (2020). Impact of academic psychological capital on academic achievement among university undergraduates: Roles of flow and selfhandicapping behavior. PsyCh Journal, 9(1), 56-66. doi:10.1002/pchj.318

Bakker, D. J., Lyons, S. T., \& Conlon, P. D. (2017). An exploration of the relationship between psychological capital and depression among first-year doctor of veterinary medicine students. Journal of Veterinary Medical Education, 44(1), 50-62. doi:10.3138/jvme.0116-006R

Brown, T. A. (2006). Confirmatory factor analysis for applied research. New York, NY: Guilford.

Byrne, B. M. (2010). Structural equation modeling with AMOS: Basic concepts, applications, and programming. New York, NY: Routledge. 
Carmona-Halty, M., Salanova, M., Llorens, S., \& Schaufeli, W. B. (2019). How psychological capital mediates between study-related positive emotions and academic performance. Journal of Happiness Studies, 20(2), 605-617. doi:10.1007/ s10902-018-9963-5

Carmona-Halty, M., Schaufeli, W. B., \& Salanova, M. (2019). Good relationships, good performance: The mediating role of psychological capital - A three-wave study among students. Frontiers in Psychology, 10, 306. doi:10.3389/ fpsyg.2019.00306

Cassep-Borges, V., Balbinotti, M. A. A., \& Teodoro, M. L. M. (2010). Tradução e validação de conteúdo: Uma proposta para a adaptação de instrumentos [Translation and content validation: A proposal for the adaptation of instruments]. In L. Pasquali (Org.), Instrumentação psicológica: Fundamentos e práticas [Psychological instrumentation: Fundamentals and practices] (pp. 506-520). Porto Alegre, RS: Artmed.

Cid, D. T., Martins, M. C. F., Dias, M., \& Fidelis, A. C. F. (2020). Psychological Capital Questionnaire (PCQ-24): Preliminary evidence of psychometric validity of the Brazilian version. Psico-USF, 25(1), 63-74. doi:10.1590/ 1413-82712020250106

Datu, J. A. D., King, R. B., \& Valdez, J. P. M. (2016). Psychological capital bolsters motivation, engagement, and achievement: Cross-sectional and longitudinal studies. The Journal of Positive Psychology, 13(3), 260-270. doi:10.1080/17439760.2016.1257056

Datu, J. A. D., \& Valdez, J. P. M. (2016). Psychological capital predicts academic engagement and well-being in Filipino high school students. The Asia-Pacific Education Researcher, 25(3), 399-405. doi:10.1007/s40299-015-0254-1

Ersan, N., Fişekçioğlu, E., Dölekoğlu, S., Oktay, İ., $\&$ İlgüy, D. (2017). Perceived sources and levels of stress, general self-efficacy and coping strategies in clinical dental students. Psychology, Health \& Medicine, 22(10), 1175-1185. doi:10.1080/13548506.2017.1286359

Ferrando, P. J., \& Lorenzo-Seva, U. (2017). Program FACTOR at 10: Origins, development and future directions. Psicothema, 29(2), 236-240. doi:10.7334/psicothema2016.304

Franco, V. R., Valentini, F., \& Iglesias, F. (2017). Introdução à análise fatorial confirmatória [Introduction to confirmatory factor analysis]. In B. F. Damásio \& J. C. Borsa (Orgs.), Manual de desenvolvimento de instrumentos psicológicos [Development manual for psychological tools] (pp. 295-322). São Paulo, SP: Vetor.

Freiberg Hoffmann, A., Stover, J. B., de la Iglesia, G., \& Fernández Liporace, M. (2013). Correlaciones policóricas y tetracóricas en estudios factoriales exploratorios y confirmatorios [Polychoric and tetrachoric correlations in exploratory and confirmatory factor studies]. Ciencias Psicológicas, 7(2), 151-164. Retrieved from http://www.scielo.edu.uy/scielo.php?script=sci arttext\&pid=S1688-42212013000200005
Harms, P. D., Krasikova, D. V., \& Luthans, F. (2018). Not me, but reflects me: Validating a simple implicit measure of psychological capital. Journal of Personality Assessment, 100(5), 551-562. doi:10.1080/00223891.2018.1480489

Hazan Liran, B., \& Miller, P. (2019). The role of psychological capital in academic adjustment among University students. Journal of Happiness Studies, 20(1), 51-65. doi:10.1007/ s10902-017-9933-3

Hobfoll, S. (2002). Social and psychological resources and adaptation. Review of General Psychology, 6(4), 307-324. doi:10.1037/1089-2680.6.4.307

Hernández Nieto, R. A. (2002). Contribuciones al análisis estadístico [Contributions to statistical analysis]. Mérida, España: Universidad de Los Andes.

International Test Commission. (2017). The ITC Guidelines for Translating and Adapting Tests (2nd ed.). Retrieved from https://www.intestcom.org/files/guideline_test_ adaptation_2ed.pdf

Kamei, H., Ferreira, M. C., Valentini, F., Peres, M. F. P., Kamei, P. T., \& Damásio, B. F. (2018). Psychological Capital Questionnaire - Short Version (PCQ-12): Evidence of validity of the Brazilian version. Psico-USF, 23(2), 203-214. doi:10.1590/141382712018230202

Landis, J. R., \& Koch, G. G. (1977). The measurement of observer agreement for categorical data. Biometrics, 33(1), 159-174. doi:10.2307/2529310

Li, S., Zhao, F., \& Yu, G. (2021). Social exclusion and depression among college students: A moderated mediation model of psychological capital and implicit theories. Current Psychology, 40(3), 1144-1151. doi:10.1007/s12144-018-0036-Z

Liao, R. X., \& Liu, Y. H. (2016). The impact of structural empowerment and psychological capital on competence among Chinese baccalaureate nursing students: A questionnaire survey. Nurse Education Today, 36, 31-36. doi:10.1016/j.nedt.2015.07.003

Lima, L. G., \& Nassif, V. M. J. (2017). Similitudes entre teoria social cognitiva, Capital Psicológico [Similarities between cognitive social theory, psychological capital]. Gestão e Planejamento, 18, 369-385. doi:10.21714/2178-8030gep. v18.4517

Luthans, B. C., Luthans, K. W., \& Avey, J. B. (2013). Building the leaders of tomorrow: The development of academic psychological capital. Journal of Leadership \& Organizational Studies, 21(2), 191-199. doi: $10.1177 / 1548051813517003$

Luthans, F., Avey, J. B., Avolio, B. J., \& Peterson, S. J. (2010). The development and resultingperformance impact of psychological capital. Human Resource Development Quarterly, 21(1), 41-67. doi:10.1002/hrdq.20034 
Luthans, F., Avolio, B. J., Avey, J. B., \& Norman, S. M. (2007). Positive psychological capital: Measurement and relationship with performance and satisfaction. Personnel Psychology, 60(3), 541-572. doi:10.1111/j.17446570.2007.00083.x

Luthans, F., Youssef-Morgan, C. M., \& Avolio, B. J. (2015). Psychological capital and beyond. New York, NY: Oxford University Press.

Martínez, I. M., Meneghel, I., Carmona-Halty, M., \& YoussefMorgan, C. M. (2019). Adaptation and validation to Spanish of the Psychological Capital Questionnaire-12 (PCQ-12) in academic contexts. Current Psychology. Advance online publication. doi:10.1007/s12144-019-00276-Z

Martínez, I. M., Youssef-Morgan, C. M., Chambel, M. J., \& Marques-Pinto, A. (2019). Antecedents of academic performance of university students: Academic engagement and psychological capital resources. Educational Psychology, 39(8), 1047-1067. doi:10.1080/01443410.2 019.1623382

Mukaka, M. M. (2012). Statistics corner: A guide to appropriate use of correlation coefficient in medical research. Malawai Medical Journal, 24(3), 69-71. Retrieved from https://www. ncbi.nlm.nih.gov/pmc/articles/PMC3576830/

Patias, N. D., Machado, W. D. L., Bandeira, D. R., \& Dell'Aglio, D. D. (2016). Depression Anxiety and Stress Scale (DASS-21) - Short Form: Adaptação e validação para adolescentes brasileiros [Depression Anxiety and Stress Scale (DASS-21) - Short Form: Adaptation and validation for Brazilian adolescents]. Psico-USF, 21(3), 459-469. doi:10.1590/1413-82712016210302

Peters, G.-J. Y. (2014). The alpha and the omega of scale reliability and validity: Why and how to abandon Cronbach's alpha and the route towards more comprehensive assessment of scale quality. The European Health Psychologist, 16(2), 56-69. doi:10.31234/osf.io/h47fv

Qudsyi, H., \& Putri, M. I. (2016). Self-efficacy and anxiety of national examination among high school students. Procedia - Social and Behavioral Sciences, 217, 268-275. doi:10.1016/j.sbspro.2016.02.082

R Core Team. (2017). R: A Language and Environment for Statistical Computing. Retrieved from https://www.gbif. $\mathrm{org} / \mathrm{pt} / \mathrm{tool} / 81287 / \mathrm{r}$-a-language-and-environment-forstatistical-computing

Rosseel, Y. (2012). lavaan: An R Package for structural equation modeling. Journal of Statistical Software, 48(2), 1-36. doi:10.18637/jss.v048.i02

Segabinazi, J. D., Zortea, M., Zanon, C., Bandeira, D. R., Giacomoni, C. H., \& Hutz, C. S. (2012). Escala de afetos positivos e negativos para adolescentes: Adaptação, normatização e evidências de validade [Scale of positive and negative affects for adolescents: Adaptation, standardization and evidence of validity]. Avaliação Psicológica, 11(1), 1-12. Retrieved from http://pepsic.bvsalud.org/scielo. php?script=sci_arttext\&pid=S1677-04712012000100002
Seligman, M. E. P., Ernst, R. M., Gillham, J., Reivich, K., \& Linkins, M. (2009). Positive education: Positive psychology and classroom interventions. Oxford Review of Education, 35(3), 293-311. doi:10.1080/03054980902934563

Selvaraj, P. R., \& Bhat, C. S. (2018). Predicting the mental health of college students with psychological capital. Journal of Mental Health, 27(3), 279-287. doi:10.1080/09638237.2018.1469738

Schönfeld, F. S., \& Mesurado, B. (2020). Adaptación del Cuestionario de Capital Psicológico al ámbito educativo en una muestra Argentina [Adaptation of the Psychological Capital Questionnaire in the educational context in na Argentine sample]. Propósitos y Representaciones, 8(1), e315. doi:10.20511/pyr2020.v8n1.315

Siegel, S., \& Castellan, N. J., Jr. (1988). Nonparametric statistics for the behavioral sciences. New York, NY: McGraw-Hill.

Siqueira, M. M. M., Martins, M. C. F., \& Souza, W. S. (2014). Capital Psicológico no trabalho [Psychological capital at work]. In M. M. M. Siqueira (Org.), Novas medidas do comportamento organizacional: Ferramentas de diagnóstico e de gestão [New measures of organizational behavior: Diagnostic and management tools] (pp. 65-78). Porto Alegre, RS: Artmed.

Singhal, H., \& Rastogi, R. (2018). Psychological capital and career commitment: The mediating effect of subjective wellbeing. Management Decision, 56(2), 458-473. doi:10.1108/ MD-06-2017-0579

Smith, G. D., \& Yang, F. (2017). Stress, resilience and psychological well-being in Chinese undergraduate nursing students. Nurse Education Today, 49, 90-95. doi:10.1016/j. nedt.2016.10.004

Trigueros, R., Padilla, A. M., Aguilar-Parra, J. M., Rocamora, P., Morales-Gázquez, M. J., \& López-Liria, R. (2020). The influence of emotional intelligence on resilience, test anxiety, academic stress and the Mediterranean diet. A study with University students. International Journal of Environmental Research and Public Health, 17(6), 2071. doi:10.3390/ijerph17062071

Viseu, J., Jesus, S. N., Rus, C., Nunes, H., Lobo, P., \& CaraLinda, I. (2012). Capital Psicológico e sua avaliação com o PCQ-12 [Psychological Capital and its evaluation with the PCQ-12]. Estudos Contemporâneos da Subjetividade, 2(1), 4-16. Retrieved from http://www.periodicoshumanas. uff.br/index.php/ecos/article/viewFile/792/666

Wu, S., Xu, Z., Zhang, Y., \& Liu, X. (2019). Relationship among psychological capital, coping style and anxiety of Chinese college students. Rivista di Psichiatria, 54(6), 264-268. doi:10.1708/3281.32545 
Fabiola Rodrigues Matos is a Ph.D Student at the Universidade Federal do Espírito Santo, Vitória-ES, Brazil.

Alexsandro Luiz De Andrade is Professor at the Universidade Federal do Espírito Santo, Vitória-ES, Brazil.

Authors' Contribution:

All authors made substantial contributions to the conception and design of this study, to data analysis and interpretation, and to the manuscript revision and approval of the final version. They also assume public responsibility for the content of the manuscript.

Associate Editor:

Fabio Scorsolini-Comin

Received: Oct. 28, 2020

1st Revision: Feb. 24, 2021

Approved: Mar. 17, 2021

How to cite this article:

Matos, F. R., \& De Andrade, A. L. (2021). Psychometric properties of the psychological capital scale in the student context (PsyCap-S). Paidéia (Ribeirão Preto), 31, e3123. doi:https://doi.org/10.1590/1982-4327e3123 